\title{
Mezi učitelstvím a youtuberstvím: profesní sebepojetí učitelů publikujících vzdělávací videa na YouTube ${ }^{1}$
}

\author{
Klára Holíková \\ Masarykova univerzita, Filozofická fakulta, Ústav pedagogických věd
}

Redakci zasláno 24. 9. 2017 / upravená verze obdržena 21. 1. 2018 /

k uveřejnění přijato 28. 1. 2018

\begin{abstract}
Abstrakt: V současnosti narůstá význam platforem pro sdílení videí, které mají velké množství uživatelů včetně učitelů. Cílem této studie je zjistit, jak se promítá publikování vzdělávacích videí na YouTube do profesního sebepojetí učitelů. Pro zodpovězení této otázky je využito kvalitativní metodologie, konkrétně designu vícepřípadové studie explorativního charakteru. Pro studii jsou záměrně vybrány dva odlišné př́ípady učitelů. Hlavním kritériem výběru je jejich vysoká publikační aktivita na YouTube (30 a více videí) a sledovanost videí (400 000 a více zhlédnutí), s tím je spojená informační bohatost jejich kanálů. Zdrojem dat jsou polostrukturované rozhovory s učiteli. K triangulaci těchto dat slouží data zveřejněná učiteli na jejich YouTube kanálech (videa a komentáře), která jsou zpracována prostřednictvím netnografické metodologie. Při kvalitativní analýze jsou využity analytické metody zakotvené teorie. Výsledky studie ukázaly, že vybraní učitelé začali YouTube využívat, aby lépe zprostředkovali obsah výuky svým žákům. Pozitivní reakce na jejich videa od uživatelů YouTube mimo okruh jejich žáků postupně ovlivňuje jejich chování na YouTube. Nejvýraznějším znakem profesního sebepojetí vybraných učitelů je pozitivní sebeoceňování, které se utváří na základě interakcí na YouTube a promítá se i do jejich pedagogické činnosti.
\end{abstract}

Klíčová slova: YouTube, vzdělávací video, profesní sebepojetí učitele, sebeocenění učitele, vícepř́ípadová studie, netnografie

Digitální technologie a internet jsou již nedílnou součástí naší společnosti a stále častěji jejich prostřednictvím probíhá učení. Tématu využívání informačních technologií ve výuce učiteli je v pedagogickém výzkumu věnována častá pozornost (např́klad Sutherland et al., 2004; Tondeur et al., 2008;

1 Poznámka redakce: Příspěvek byl publikován v rámci spolupráce České asociace pedagogického výzkumu a časopisu Pedagogická orientace. Spolupráce je součástí publikační strategie ČAPV podpořené projektem financovaným Radou vědeckých společností AV ČR. 
Williams et al., 2000; Zounek \& Šed'ová, 2009). V této studii je z oblasti ICT ve vzdělávání vybráno téma vzdělávacích online videí ${ }^{2}$. Ve výzkumných šetřeních zaměřených na vzdělávací online videa se tematicky odráží využití videí vzdělávacími institucemi k publikaci vlastních vzdělávacích aktivit, například (Haase, 2009); využití videí vlastních nebo již vytvořených učiteli ve výuce (například Berk, 2009; Jones \& Cuthrell, 2011; Mayora, 2009); vzdělávání prostřednictvím tvorby videí studenty (například Desmet, 2009; Mayora, 2009). Minimum výzkumů je věnováno informálnímu učení, které je oblastí, kam YouTube svojí otevřeností všem uživatelům primárně směřuje. Kvalitativní výzkumy v této oblasti provedl např́klad Tan (2013). Učení $\mathrm{v}$ tomto prostředí je iniciačním prvkem interakce mezi žáky, často přechází do zábavné roviny a s tím souvisí otázka reliability a vhodnosti obsahu videí. Výzkum proto představuje strategie žáků, kterými se s těmito podmínkami k učení vyrovnávají. Alston a Ellis-Hervey (2015) se pak ve své studii věnují specifikům neformálního vzdělávání prostřednictvím YouTube a představují doporučení pro tvorbu a postprodukci videa.

Dosavadní výzkum učení $\mathrm{v}$ prostředí YouTube je zaměřen na didaktické metody a techniky, kterých učitelé využívají, a na využití videa jako média a jeho technického zpracování. Chybí zde zaměření na učitele, a proto je tento výzkum zacílen právě na profesní sebepojetí učitelů, kteří publikují vzdělávací videa na YouTube. Přispívá tak ke stavu současného bádání otevřením tématu učitelů v neformálním prostředí YouTube. Konkrétně je zkoumáno, jak se publikování vzdělávacích videí na YouTube promítá do profesního sebepojetí učitele a s ním spojeného mínění o sobě a svých žácích a o vlastním výkonu v roli učitele (dle Lukášové, 2015).

Pro zodpovězení této otázky je využito kvalitativní metodologie, konkrétně designu vícepřípadové studie, ve které byly záměrně vybrány dva odlišné případy učitelů. Oba učitelé Adam a Ctirad založili své kanály na YouTube primárně pro své žáky a studenty. Záměrem kanálů tak byla podpora vlastní výuky ve škole. Přes původní záměr ale dochází, vzhledem k veřejné př́istupnosti videí na YouTube, k nepředpokládaným dopadům, které ovlivňují učitele Adama a Ctirada v jejich dráze učitele.

\footnotetext{
Vzdělávací online video je v kontextu tohoto výzkumu definováno jako audiovizuální soubor distribuovaný a recipovaný prostřednictvím internetu za využití informačních a komunikačních technologií (McGarr, 2009). Tato videa zastávají, mimo zábavné či informační, dominantně vzdělávací funkci a reagují při tom na aktuální vzdělávací potřeby ve společnosti (Průcha, Walterová, \& Mareš, 2001, s. 299).
} 


\section{Prostředí YouTube a učitel jako tvůrce vzdělávacích videí}

Server YouTube je živá rostoucí platforma pro šíření videí, která slouží množství uživatelů také ke vzdělávání, jak uvádějí například Alston a Ellis-Hervey (2015), Berk (2009), Desmet (2009), Dreon, Kerper a Landis (2011), Jones a Cuthrell (2011), Kellner a Kim (2010), Mayora (2009) a Tan (2013). Přesto v českém prostředí není téma v pedagogickém kontextu zkoumáno. YouTube je specifickým prostředím na pomezí úložiště videí a sociální sítě sdružující její uživatele. Záleží pak na uživateli, jak k využití tohoto serveru přistoupí, jestli bude pouze pasivním konzumentem audiovizuálního obsahu, nebo se na YouTube bude aktivně prosazovat vlastní tvorbou a interakcemi s ostatními uživateli.

Kvalitativní studie Preece a Rotmana (2010) představuje charakteristiky prostředí YouTube v oblasti utváření komunit ve skupině videoblogerů. V těchto komunitách dochází na základě interakcí mezi uživateli YouTube $\mathrm{k}$ utváření vztahů $\mathrm{s}$ emočním přilnutím jednoho ke druhému v závislosti na frekvenci a objemu osobních interakcí. Jako pouto komunity slouží sdílená idea, kterou je na YouTube zejména zveřejňování vlastní videotvorby. Mezi uživateli je pak běžná vzájemná podpora, at' už osobní, nebo v oblasti tvorby videí. Osobní komunikace mezi uživateli může přesahovat prostředí YouTube v podobě další online komunikace nebo i osobního setkání. Tan (2013) se ve své kvalitativní studii zaměřuje na YouTube př́mo v souvislosti se vzděláváním. Dochází k obdobnému závěru jako předchozí studie, ale již v pedagogickém kontextu, konkrétně v oblasti informálního učení. Uvádí, že učení prostřednictvím vzdělávacích videí na YouTube je pro žáky příjemným zážitkem. Sdílená zkušenost ze sledování konkrétních videí navíc přináší nové interakce v žákovské skupině. Učení v prostředí YouTube často přechází do zábavné roviny a s tím souvisí otázka reliability a vhodnosti obsahu videí. Výzkum proto představuje strategie žáků, jak se s těmito podmínkami k učení vyrovnávají.

Výzkum zaměřený na využití YouTube ve výuce je představen ve studii Jonese a Cuthrella (2011). Nejčastěji se jedná o snahu získat pozornost studentů. Své místo ovšem může video mít při úvodu do nového tématu, při předávání nových informací či při závěrečném opakování. YouTube může sloužit také jako zdroj pro př́ípravu učitelů na výuku bez přímého přehrávání ve výuce, kdy má učitel možnost obsahy upravit přesně pro jím vyučovanou skupinu 
studentů. Na YouTube je zde nahlíženo, jako na zdroj výukových materiálů pro učitele, obdobně toto téma zpracovává např́klad Berk (2009). Učitel coby tvůrce vzdělávacích videí na YouTube je ve kvalitativní studii Alstona a Ellis-Herveyho (2015) popsán jako praktik, který má osobní vztah k tématu, potřebu jeho publikace a případné demystifikace. Ve studii jsou představena doporučení pro postprodukci videa založená na doplnění záznamu o ilustrační vizuální prvky a hudbu. Další doporučení zahrnují využití digitálního storytellingu, humoru, upř́mnosti a skromnosti při zprostředkování učebních obsahů dospělému publiku napřríč kulturami.

Podrobnější pohled na učitele coby tvůrce vzdělávacích videí se v současném výzkumu vyskytuje spíše mimo oblast YouTube. Mezi řešená témata spadá odbornost učitele $\mathrm{v}$ rámci předávaného obsahu, využití didaktických metod a technik, využití videa jako média a vztah mezi učitelem a žákem. Co se týká odbornosti učitele, dle Hibbertové (2014) studenti ve videích užívaných pro formální vzdělávání považují učitele za nositele znalostí dané instituce. Při využití videí v neformálním vzdělávání je nutné studentovo vlastní kritické myšlení a posouzení kredibility učitele (srov. Tan, 2013).

Perkins a Snelson (2009) ve své studii mapující vzdělávání pomocí audiovizuálních médií od vynálezu filmu po současná online videa docházejí k závěru, že s vývojem média nedochází k inovacím didaktických metod a technik $\mathrm{v}$ nich užívaných. $\mathrm{V}$ současnosti tak můžeme vysledovat didaktické metody a postupy užívané již v prvních desetiletích tvorby vzdělávacích filmů. Boling a kol. (2014) představují řadu didaktických postupů užívaných ve vzdělávacích online videích i v e-learningu obecně. Jedná se např́klad o princip lešení (scaffolding) nebo koučování (coaching), tedy pomoc studentovi a monitorování aktivity studenta. Thomson, Bridgstock a Willems (2014) mezi didaktické postupy doplňují učitelovo poskytnutí kontextu a možného účelu lekce, jasné a stručné směřování k cíli. Ve výčtu dalších didaktických metod pak jmenují Boling a kol. (2014) modeling, kdy se student učí na základě pozorování experta pracujícího na úkolu, a metody artikulace a reflexe, které probíhají obdobně jako koučování ve formě komentářů k videím.

Tvorba vzdělávacího videa je náročná na technické dovednosti v závislosti na volbě technického zpracování, at' už po stránce plánování, produkce či postprodukce. Často jsou proto videa samostatných autorů velmi jednoduchá, v podobě takzvaných „mluvících hlav“ doplněných o powerpointovou prezentaci. Navzdory multimediálním možnostem videa se tak vzdělávací videa 
vyznačují minimálním využitím daného potenciálu, jak v oblasti zvuku, tak obrazu (Alston \& Ellis-Hervey, 2015; Hibbert, 2014; Thomson et al., 2014). $\mathrm{K}$ náročnější tvorbě videa dochází zejména $\mathrm{v}$ př́ípadě spolupráce učitelů a produkčních týmů (srov. Thomson et al., 2014; Chen \& Summers, 2015). Samostatní tvůrci jsou oproti týmům často limitováni materiálním zázemím a vlastními schopnostmi.

Ve výzkumu vzdělávacích online videí nechybí téma vztahu mezi učitelem a žákem. Borup, West a Graham (2012) ve své studii uvádějí, že vzdělávací videa mohou předcházet pocitu izolovanosti studentů (student's sense of distance), který vede $\mathrm{v}$ rámci online vzdělávání $\mathrm{k}$ narušení procesu učení. Při učení prostřednictvím vzdělávacích videí je tohoto pozitivního efektu dosaženo prostřednictvím studenty pocitované reálnější přítomnosti edukátora. Výzkumy zaměřené na vzdělávací online videa poukazují na pozitivní účinnost vztahu mezi učitelem a žákem, navázaného skrze video, na zlepšení přístupu k učení i studijní výsledky studentů (Kim \& Thayne, 2015) na větší chut' k učení a užitečnost videa (Lyons, Reysen, \& Pierce, 2012).

Obraz učitele coby tvůrce vzdělávacích videí je v literatuře popsán zejména prostřednictvím výzkumných šetření mezi studenty zaměřených na efektivitu videí při učení, vlastnosti a využití vzdělávacího videa a atraktivitu tohoto média pro recipienty (např́íklad Hibbert, 2014; Boling et al., 2014; Borup, et al., 2012). V současném výzkumu učitelů v prostředí YouTube jsou představeny didaktické metody a techniky, kterých využívají. Řešeno je také téma využití videa jako média a jeho technického zpracování. Objevují se rovněž výzkumy učení s použitím videí. Chybí ale zaměření přímo na učitele působící v prostředí YouTube. Otevírá se zde tedy prostor pro výzkumné šetření zaměřené na učitelovo vlastní vnímání vzdělávání prostřednictvím videí. Proto je cílem tohoto výzkumu přiblížit právě profesní sebepojetí učitelů, kteří publikují vzdělávací videa na YouTube.

\section{Profesní sebepojetí učitele}

Koncept sebepojetí patří do sociální psychologie a psychologie osobnosti. Blatný $(2010$, s. 107) definuje sebepojetí jako „souhrn představ a hodnoticích soudů, které člověk o sobě chová". Sebepojetí učitele je vedle pojetí žáka a výuky klíčovým fenoménem učitelské profesionality (Lukášová, 2015). Klechtermans (1993) zkoumá profesní vývoj učitele prostřednictvím komparativní analýzy biografii deseti belgických učitelů. Z př́iběhů profesní dráhy 
těchto učitelů rekonstruuje profesní Já učitele. Kelchtermans (1993, s. 449) představuje dvě dimenze učitelského profesního sebepojetí (retrospektivní Já a prospektivní Já). Retrospektivní Já, zaměřené na minulost, je členěno na čtyři komponenty. První, sebeobraz (selfimage), obsahuje deskriptivní Já, tedy vlastní učitelův popis sebe v profesi. Ten zahrnuje pedagogickou činnost a její význam ve vztahu k žákům, rodičům a kolegům. Druhá, sebeoceňování nebo sebeúcta (self-esteem), je hodnoticí podobou učitelova Já. Učitel hodnotí sám sebe v profesi a svoji úspěšnost $\mathrm{v}$ pedagogické činnosti s žáky, rodiči, kolegy či nadřízenými. Třetí komponenta, snahové Já, je vyjádřeno profesní motivací (job motivation), která se odvíjí již od učitelova rozhodnutí pro tuto profesi a zahrnuje změny motivace v jejím průběhu. Čtvrtá komponenta vnímání úkolu (task perception) je podobou učitelova profesního Já, která je normativní. Jedná se zde o vlastní cíle učitele a jeho nároky na žáky, rodiče, kolegy a kritéria, kterými je a jejich činnost hodnotí. Druhou dimenzí profesního Já učitelů je prospektivní Já, které odkazuje k budoucnosti, k profesní perspektivě učitele, která představuje profesní cíle a směřování učitele. Mareš a kol. (1996, s. 26-27) Kelchtermansův model profesního sebepojetí rozšiřují o aktuální dimenzi, ve které se projevují komponenty retrospektivní dimenze v př́ítomném čase. Dimenzi prospektivní (profesní perspektivu) rozšiřuje o učitelovo vnímání perspektivy jeho žáků a školy.

Profesní sebepojetí učitelů je v českém prostředí popsáno na různých stupních jejich profesní dráhy. Lazarová a Jůva (2011) se zaměřují na učitele v pozdní fázi jejich kariéry. Učitelé v této fázi mají tendence ke srovnávání různých etap své profese. Starší učitelé se hůře přizpůsobují změnám ve školní politice, byrokracii a př́stupu žáků ke studiu. K setrvání v profesi je motivuje zejména atmosféra na pracovišti a dobré vztahy s kolegy. Pravdová $(2013,2015)$ se věnuje profesnímu sebepojetí studentů učitelství, které je založené již na zkušenostech v roli žáka a praktikanta a také na motivaci studenta pro vstup do profese.

Tato studie je zaměřena na profesní sebepojetí učitelů působících ve specifickém prostředí YouTube. Cílem studie je přiblížit, jak se promítá publikování vzdělávacích videí na YouTube do profesního sebepojetí učitelů. Záměrem je popsat jednotlivé dimenze profesního sebepojetí učitelů, tedy jejich retrospektivní Já a s ním spojené profesní představy o sobě při vstupu do prostředí YouTube. Aktuální Já učitelů je popsáno skrze sebeoceňování a interakce s recipienty a dalšími tvůrci videí. Prospektivní Já se váže na představu ideálního Já, kterou učitelé ve své profesi chovají. 


\section{Metodologie}

Cílem této studie je zodpovědět otázku: Jak se promítá publikování vzdělávacích videí na YouTube do profesního sebepojetí učitelů?

Hlavní výzkumná otázka byla na základě rovin profesního sebepojetí učitele strukturována na dílčí výzkumné otázky:

1) Jaké je retrospektivní Já učitelů coby tvůrců vzdělávacích videí v prostředí YouTube?

2) Jaké je aktuální Já učitelů coby tvůrců vzdělávacích videí v prostředí YouTube?

3) Jaké je prospektivní Já učitelů coby tvůrců vzdělávacích videí v prostředí YouTube?

K formulaci otázky došlo na základě vynořených informací při detailním popisu obou případů, jak doporučují Yin a Campbell (2003). Téma profesního sebepojetí učitelů bylo Stakem (2013) identifikováno jako důležité napříč prrípady.

K naplnění zvoleného cíle je užito kvalitativní metodologie, konkrétně designu vícepř́ípadové studie explorativního charakteru, jak ji popisuje Mareš (2013). Tento typ prŕípadové studie umožňuje odhalení příčinných vztahů v rámci zvolených př́ípadů a popis jejich struktury. Yin a Campbell (2003) uvádějí jako hlavní strategii př́ípadové studie zkoumání sociálního jevu v reálném kontextu. Tím je v našem př́ípadě online prostředí YouTube, proto vychází metodologie této studie také z netnografického diskurzu podle Kozinetse (2010). V netnografii jsou využívány etnografické postupy pro výzkum dějů odehrávajících se v kyberprostoru. Tento přístup vede k etnografickému porozumění kultuře vybrané skupiny, která je aktivní online. Zdrojem dat je zde komunikace zprostředkovaná ICT (Kozinets, 2010). Přístupy vícepřípadové studie a netnografie společně umožňují detailní a komplexní popis zvolených př́padů a jejich struktury díky možnosti sledovat děje odehrávající se online a tyto dále analyzovat prostřednictvím digitální stopy, kterou zanechávají.

Mezi hlavní charakteristiky případové studie, jak ji popisují Yin a Campbell (2003), patří jasné vymezení př́padu, kdy má př́pad jako předmět výzkumu jasně vymezené časové i prostorové hranice. Vícepřípadová studie je zaměřena na působení učitelů v prostředí YouTube, od vložení prvního veřejného 
vzdělávacího videa na jejich kanál do ukončení sběru dat (březen 2017). Zkoumaným případem je kanál učitele na serveru YouTube. Pozornost je věnována aktivitě učitele na YouTube v rámci jeho vlastního kanálu. Aktivitou se zde rozumí interakce s recipienty ve formě publikování videí a komunikace prostřednictvím komentářu.

\subsection{Volba př́padů, sběr a analýza dat}

Výběr zkoumaných učitelů vychází z dlouhodobého průzkumu prostředí vzdělávacích online videí. ${ }^{3}$ Výběr je založen v souladu s netnografickou metodologií na relevanci k tématu, dále na aktivitě, interaktivitě, vlivnosti, heterogennosti a bohatosti dat, které poskytuje zkoumaná skupina (Kozinets, 2010). Do výběru jsou zařazeny kanály na YouTube, které jsou zaměřeny na vzdělávání a jsou tvořeny učiteli. Oslovováni byli autoři kanálů, kteří se $\mathrm{v}$ tomto prostředí prezentují jako učitelé pod svými osobními profily. Z toho je zřejmé, že mají založený vlastní kanál a nejedná se pouze o součinnost $\mathrm{s}$ iniciativou vzdělávací organizace, na které působí. Vzhledem k rozmanitosti obsahů vzdělávacích videí v prostředí YouTube jsou pro výzkum vybírány pouze kanály, jejichž obsahy se překrývají s kurikulem základních a středních škol. Výběr je takto zúžen, aby př́ípady vycházely z obdobného kontextu a bylo možné je mezi sebou porovnávat.

Celkem bylo na serveru YouTube podrobně analyzováno 12 vzdělávacích kanálů. ${ }^{4} \mathrm{Z}$ tohoto vzorku byly pro tuto studii vybrány dva př́pady učitelů tvořících vzdělávací videa. Šlo o učitele, které je možné označit na YouTube za úspěšné z hlediska množství nahraných videí a počtu jejich zhlédnutí. Vybrané kanály mají více než 400000 zhlédnutí (na celkovém počtu videí $\mathrm{v}$ rámci jednoho profilu). Hlavní motivací k takovému výběru byla bohatost na netnografická data a zajištění aktivní a vlivné skupiny. Zároveň se jedná

3 Téma informálního učení na YouTube je předmětem dizertační práce, kterému se nyní věnuji dva roky coby výzkumnice $\mathrm{v}$ oblasti pedagogických věd. Vzdělávacích videí na YouTube využívám také ve výuce při své práci učitelky na gymnáziu i ve vlastním volném čase. Videa vybraných učitelů Adama a Ctirada jsem využila výhradně za účelem výzkumu a můj vztah k oběma respondentům je čistě profesionální.

4 Vyhledávání kanálů a videí v databázi YouTube spočívá v zadávání klíčových slov odkazujících ke školním předmětům (např. matematika, český jazyk, anglický jazyk, dějepis, přírodopis, zeměpis, fyzika), případně k jejich obsahu (zlomky, trojčlenka, dělení, násobení, přítomný čas, budoucí čas, rozbor vět apod.). Je využíváno i možnosti automatického přehrávání, kdy byla další videa automaticky doporučována systémem na základě podobnosti. Tímto způsobem bylo prohledáno přibližně čtyři sta kanálů. 
o variující případy v oblastech délky praxe v prostředí školy i YouTube, vyučovaného předmětu, motivace i prŕístupu k tvorbě vzdělávacích videí a prostředí YouTube samotnému. Při výběru případů tak byla dodržena hlavní kritéria uvedená Stakem (2013). Jedná se jednak o vzájemnou relevantnost případů, která je zajištěna výběrem učitelů, jejichž vzdělávací videa obsahově vycházejí z kurikula základních a středních škol, jednak o obdobnou míru aktivity na YouTube $\mathrm{z}$ hlediska množství nahraných videí a aktivity $\mathrm{v}$ diskusích a rovněž o poskytnutí diverzity napříč případy pro daný kontext, která je zajištěna volbou variujících případů.

Zdrojem dat jsou zejména hloubkové rozhovory s učiteli. ${ }^{5}$ Polostrukturované rozhovory probíhaly na základě předem připraveného schématu založeného na oblastech: tvorba videa, komunikace s recipienty videí a vztah k prostředí YouTube. Rozhovorům předcházela analýza YouTube kanálů vybraných učitelů a v rozhovorech bylo konkrétně reflektováno, jak učitelé tvoří videa i jak reagují na komentáře recipientů. Zdrojem dat netnografického charakteru jsou informace, kterými se učitelé prezentují v rámci svých kanálů na serveru YouTube. Jedná se zejména o samotná videa a komentáře k nim. Celkem bylo analyzováno 70 videí v rozsahu 3-50 minut a komentáře ke každému videu v rozsahu 3-7 stran. ${ }^{6}$

Veškerá data ${ }^{7}$ byla zpracována $\mathrm{v}$ softwaru Atlas.ti prostřednictvím kódovacích postupů kvalitativní analýzy, induktivního otevřeného kódování a memo poznámek (Švaříček \& Šed'ová, 2007). Z otevřeného kódování vzešlo několik klíčových kategorií: interakce na YouTube, sebeocenění, úspěch, motivace, pomoc, profesionalizace na YouTube, inovace pedagogické činnosti. Ke vzniklým kategoriím byly přiřazeny jednotlivé kódy. Mezi kategoriemi byly nalezeny vztahy, vyjádřené jádrovými tvrzeními ${ }^{8}$. Nálezy byly konstantně

5 První z rozhovorů se odehrál vzhledem k zahraničnímu pobytu respondenta Adama za využití Skype videohovoru a trval přibližně hodinu. Rozhovor s respondentem Ctiradem se odehrál na základní škole, kde vyučuje, a trval hodinu a půl. Po doslovném přepsání mají texty rozhovorů rozsah 45 stran.

6 Vzhledem $\mathrm{k}$ charakteru zkoumaného prostředí je nutno zdůraznit, že u všech sebraných netnografických dat se jedná o záznam sebeprezentace jejich autorů, nikoli o objektivní záznam komunikace. Autoři komentářu mají možnost své komentáře následně mazat, podobně majitel kanálu má možnost mazat libovolný obsah na svém kanálu.

7 Videa, komentáře $\mathrm{k}$ videím a rozhovory s učiteli.

8 Adam se snaží profesionalizovat v prostředí YouTube. Ctirad se snaží o inovaci vlastní pedagogické činnosti. Ctiradovým cílem je recipientům pomoci zvládat školní povinnosti. Adamovým cílem je recipienty motivovat. Interakce s recipienty (studenty, tvưrci i učiteli) upevňují sebeúctu učitelů Adama a Ctirada. 
komparovány, jak doporučují Švaříček a Šed'ová (2007), v kontextu obou případů i v kontextu jednotlivých zdrojů dat (videa, komentáře k videím a rozhovory). Text př́padové studie vzniknul opětovným přiřazením dat k jednotlivým tvrzením a jejich interpretací.

Na server YouTube je nazíráno jako na veřejný prostor. Z něj byly analyzovány pouze veřejné příspěvky. Tato data netnografického charakteru jsou anonymizována, aby nemohlo dojít k dohledání participantů. Stejně tak jsou anonymizována data z rozhovorů. Participanti poskytli informovaný souhlas k rozhovorům, souhlasili s nahráváním rozhovorů a byli seznámeni $\mathrm{s}$ účelem výzkumu.

\subsection{Charakteristika prostředí YouTube}

Pro uvedení do kontextu výzkumu je nutné zmínit základní charakteristiky YouTube.com jako vybrané platformy pro sdílení videí. Uživatelé YouTube mají na výběr, zda budou videa distribuovat široké veřejnosti, nebo jestli je budou sdílet neveřejně pouze s pozvanými diváky. Proces nahrávání videí je velmi jednoduchý. I nezkušený uživatel si tak na serveru YouTube může vytvořit vlastní kanál. $V$ rámci svého kanálu má možnost využít řady nástrojů k jeho správě. Rozhoduje o množství zveřejněných dat, jedná se zejména o seznam videí a jejich charakteristiky, tedy jejich hodnocení, počet zhlédnutí, nebo množství odběratelů daného kanálu. Uživatel může poskytnout kontaktní údaje. Rozhoduje, zda mohou ostatní uživatelé připsat ke kanálu či jednotlivým videím komentáře (Rotman, Golbeck, \& Preece, 2009). YouTube umožňuje více způsobů komunikace mezi uživateli. Jedná se zejména o reakce na videa formou jejich hodnocení, formou ratingu videí ${ }^{9}$ či psaným komentářem (Preece \& Rotman, 2010).

Na základě interakcí uživatelů vzniká dle Preece a Rotmana (2010) na YouTube kultura, která je založená na komunitou sdílených významech jednotlivých symbolů tohoto prostředí. Specifická kultura YouTube je založena na termínech, které uživatelé používají, a jejich sdílené zkušenosti v tomto prostředí. ${ }^{10}$

\footnotetext{
Pomocí symbolů líbí - nelíbí.

10 Mezi unikátní termíny kultury YouTube odkazující k subjektům v ní působícím patří například slovo youtuber odkazující k oddanému uživateli YouTube. Dalším termínem je hater odkazující k tyranům útočícím na youtubery. Mezi sdílené zkušenosti uživatelů patří pozitivní utváření vztahů i konflikty mezi nimi.
} 
YouTube tedy ve své podstatě není jen úložištěm audiovizuálních souborů, ale je také sociální sítí, která sdružuje miliony uživatelů. Mezi nimi dochází k interakcím, které v tomto prostředí zanechávají digitální stopu. Primárním typem interakce je samotná recepce videí. Zde se jedná o komunikaci od tvůrce videa $\mathrm{k}$ recipientovi. Zhlédnutí videa je $\mathrm{v}$ prostředí YouTube zaznamenáno a každé video je doprovázeno údajem o počtu zhlédnutí. Další komunikace směřuje od recipienta $\mathrm{k}$ autorovi videa, recipient má možnost ohodnotit video, př́ípadně ukázat př́izeň autorovi videa přihlášením se $\mathrm{k}$ odběru videí z jeho kanálu. Otevřeným způsobem komunikace, která funguje obousměrně, jsou komentáře k videím. Zde mají recipienti i autor prostor $\mathrm{k}$ diskusi, založené zpravidla na prožitku recipienta po zhlédnutí videa.

\subsection{Charakteristika respondentů a jejich videotvorby}

Oba učitelé mají několik let praxe s výukou ve škole i na YouTube, kde jsou stále aktivní. Bud' publikují nová videa, nebo se zapojují v sekci komentářů u videí stávajících, udržují tak kontakt se svými diváky.

Tabulka 1

Charakteristiky respondentů

\begin{tabular}{|c|c|c|}
\hline & Adam & Ctirad \\
\hline Vzdělání & Mgr., Učitelství cizího jazyka & Ph.D., ICT ve vzdělávání \\
\hline Praxe & $\begin{array}{c}\text { výuka na gymnáziu, } \\
\text { soukromé kurzy, přednášky } \\
\text { pro školy a učitele, kurzy } \\
\text { na VŠ }\end{array}$ & $\begin{array}{l}\text { výuka na ZŠ (nyní zástupce } \\
\text { ředitele), gymnáziu a VŠ }\end{array}$ \\
\hline Délka praxe & 5 let $*$ & 15 let * \\
\hline Výuka & cizí jazyk & matematika \\
\hline Tvorba videí na YouTube & 2 roky $*$ & 7 let $*$ \\
\hline Počet videí na YouTube & 30 videí $*$ & 40 videí $*$ \\
\hline Počet odběratelů & $8300 *$ & $1800 *$ \\
\hline Počet zhlédnutí & $601100 *$ & $400000 *$ \\
\hline
\end{tabular}

* Zaokrouhlené údaje k datu 6. 3. 2017.

Prvním komunikovaným obsahem od učitelů k recipientům je jejich video. Oba učitelé využívají k natáčení přirozených podmínek domácího prostředí či školy a ve videích vystupují sami. Délka videí obou učitelů se pohybuje mezi třemi a třiceti minutami. U učitele Ctirada se mění způsob záznamu 
vzdělávacích videí. Základní typy jeho videí jsou tři, všechny jsou založeny na zápisu výpočtů doprovázených synchronním komentářem. ${ }^{11}$ Videa učitele Adama jsou založena na záznamu jeho výkladu, který natáčí v polodetailu. ${ }^{12}$ $\mathrm{V}$ ranějších videích neužíval postprodukce a text či schémata ukazoval divákům napsané na papíré. $V$ aktuálnějších videích již postprodukce pro vkládání textu užívá. U videí učitele Adama je jasně patrný vývoj ve využívání postprodukce a lepší techniky, zejména při záznamu zvuku.

Obsah videí u učitele Ctirada kopíruje kurikulum matematiky pro druhý stupeň základní školy. Ctiradova videa jsou založena na řešení konkrétních příkladů, na kterých vysvětluje obecné principy řešení matematických úloh. Ve videích se projevuje jeho postoj k tvorbě, v němž je zásadní srozumitelné předání obsahu pro možnost domácího procvičování jeho žáků. Toto se projevuje absencí úvodu do učiva či například motivace ke sledování zábavnou formou. Ctiradova tvorba je typická přenosem jeho zvyků ze školy do videí. Udržuje si odstup a dominantní roli. Ctirad v jednom z videí rŕká: „Komu se to nelíbí, má samozřejmě šanci mně to jít na tabuli předvést sám." Tento typ komunikace není v prostředí YouTube běžný a je vztažený k prezenční výuce v prostředí základní školy. Návaznost na školní praxi je hlavním charakteristickým znakem Ctiradových videí a vypovídá o jeho profesním sebepojetí učitele.

Obsah Adamových videí také částečně vychází ze školního kurikula. Jedná se o výklad a procvičování gramatických jevů, procvičování výslovnosti nebo pro studenty problematických jevů. Hlavní rozdíl ve srovnání se Ctiradovým seznamem videílze spatřit ve videích, kde Adam na svém př́íkladu recipientům radí, jak se učit a jaké pomůcky k učení používat, nebo kde se Adam představuje. Adam pak v rozhovoru výběr témat videí odůvodňuje: „První kritérium je, aby to bylo pro široký záběr, a pak se snažím vybírat věci, který si ř́kám, že by ty lidi mohly jako oslovit, že to takhle jinde jako nemají." Adam ve videích klade důraz na představení tématu a motivaci recipientů ke sledování videa. Nabízí jim praktické využití obsahu videa, snaží se o přátelský přístup a povzbuzování recipientů formou ujištování o jejich schopnostech. Charakteristický je pro Adama živý výklad, při kterém využívá častých gest, práce s hlasem, zapojení mikropř́iběhů. Snaží se tak o interaktivnost videí,

11 Prvním je snímání zápisu na papír, dalším typem je zápis na tabuli (whiteboard), posledním typem je záznam výpočtů z interaktivní tabule.

12 Je tedy ve videích zpravidla vidět od hlavy do poloviny hrudi. Tento způsob záznamu mu umožňuje doprovod výkladu častými gesty rukou a výraznou mimikou. 
která má přispět k aktivní recepci videa. Při procvičování klade recipientům otázky, nechává jim prostor k hledání řešení úkolu a vede s nimi tímto způsobem imaginární dialog. Důraz klade také na rozloučení s recipienty a vyzývá je k reakcím na jeho videa. Úvodními frázemi recipientům usnadňuje zapamatovatelnost svého kanálu a tvoří tak vlastní značku. Tato snaha může být považována za iniciativu pro integraci do prostředí YouTube.

\section{$4 \quad$ Výsledky výzkumu}

$\mathrm{Na}$ základě realizovaných výzkumů dokážeme zjistit, jak učitelé tvoří vzdělávací videa, jakých didaktických prostředků k tomu využívají i jak výsledná videa působí na studenty. Nejasné zůstává, jak na učitele a jeho profesní sebepojetí působí přenesení jeho výuky prostřednictvím videa mimo školu do prostředí YouTube, kde je volně dostupná všem. Jak reakce recipientů a interakce s nimi působí na profesní sebepojetí učitelů?

\subsection{Retrospektivní Já učitele-youtubera}

Sociální sít' pro sdílení videí YouTube je otevřený systém, který lze z pozice autora videí využít $\mathrm{k}$ nejrůznějším záměrům. Pro retrospektivní Já učitelů Adama a Ctirada je významný jejich první tvůrčí vstup do prostředí YouTube. Učitelé Adam a Ctirad začali využívat YouTube k řešení složitých situací, které vzniky při jejich prezenční výuce.

Ctirad: Vzdělávací online videa vznikla [...] tak, že jsem neuměl dětem ukázat, jak se měří elektrické napětí a proud, ten elektrický měřák je hrozně malinkatá záležitost [...]. Takže jsem přemýšlel, jak to těm dětem ukázat, jestli si všechny svolat kolem sebe, pak nikdo nic neuvidí, nebo po částech.

Učitel Ctirad se potýkal s nemožností zprostředkovat svým žákům demonstraci postupu při fyzikálním měření, rozhodl se tedy pro využití videa jako lupy. U Adama se jednalo o zprostředkování záznamu přednášky nepřítomným a možnost uspokojit potřeby většího množství zájemců o jeho soukromé lekce, než jaké je Adam schopen prezenčně učit:

Já měl mít povídání o tom, jak se učit [...]. Ona to chtěla vidět a onemocněla a mě napadlo, že bych jí to mohl nahrát. [...] Po mně chce třeba učení víc lidí, než stíhám učit, a tohle [natáčení videí] je třeba způsob, jak se můžu namnožit a jak to může být př́stupné každému. 
Video tak bylo oběma učiteli nejprve využito ke zlepšení prezenční výuky. Díky možnosti záznamu a přenosu reality, případně jejího upravení. V Adamově případě šlo o záznam výukové situace a její přenos v čase a prostoru, Ctirad využil videa za účelem rozšśřrení reality.

Učitelé Adam i Ctirad vstupovali do prostředí YouTube bez ambice oslovit větší skupinu recipientů. Svá první videa vytvořili pro jasně určený úzký okruh diváků. YouTube oba využili jako dostupný distribuční kanál pro vlastní videa.

Adam: Takže vlastně jsem to hodil na internet hlavně pro ni a nějak jsem neřešil, že jsem to nenastavil jako soukromé. [...] Vlastě mě tehdy vůbec nenapadlo, že by to mohlo mít nějaký větší dosah.

Oba učitelé měli při vstupu do prostředí YouTube vytvořený prekoncept YouTube jako úložiště audiovizuálních souborů, které bude pohodlně sloužit $\mathrm{k}$ distribuci videí určeným recipientům ze skupiny vlastních žáků a studentů. Ctirad: „Jak chcete sdílet video, aby ho všichni otevřeli na jakémkoli zařízení? YouTube vidí každej všude." V první fázi vstupu do prostředí YouTube bylo počínání učitelů spíše intuitivní. Učitelé Adam a Ctirad si nepřipouštěli otevřenost prostředí YouTube a s ním spojenou veřejnou dostupnost videí. Videa oba vnímali jako rozšíření vzdělávacích materiálů pro vlastní okruh žáků. Prekoncept YouTube jako snadno př́istupného úložiště se u učitelů po vstupu do tohoto prostředí změnil. U obou došlo k rozšíření skupiny recipientů od vlastních žáků ke statisícům uživatelů YouTube. S tímto rozšířením je spojeno překročení prezenční pedagogické činnosti ve školní výuce. Způsob orientace na novou skupinu recipientů je pomyslným rozcestníkem, kde se trajektorie zkoumaných učitelů dělí.

Adam: Pak na základě toho videa vlastně mě oslovil Evžen, a možná ho znáš, on má takový server, 123 [anonymizováno] se to jmenuje, kde učí matiku a on je fakt docela dobrej na to. [...] A s ním jsem vlastně natočil první ten kurz a to bylo poprvé, kdy mě napadlo, že by se tím dalo třeba aji živit, víš, něco jako, jako vážného.

Adam v prostředí YouTube navazuje nové kontakty a ubírá se cestou profesionalizace v oblasti vzdělávacích videí, která je spojena s finanční výnosností a značí pro něj, jak sám říká, něco „vážného“. Ke zvolení tohoto profesního směru Adama vede vliv kolegy Evžena, který mu nabídnul spolupráci. Př́ležitost profesionalizace v prostředí YouTube dostává i učitel Ctirad. 
Tazatelka: A neoslovovali vás $\mathrm{k}$ další spolupráci?

Ctirad: Oslovovali, ale [...] pro mě jsou videa zábava, dobrej nástroj pro děti [má na mysli své žáky ve škole], ale rozhodně to není, co bych chtěl [míněno profesně].

Profesní směřování učitele Ctirada zůstává nezměněné, zakotvené v jeho školní pedagogické činnosti, kde videa používá.

Oba učitele vedly k tvorbě prvních videí podobné pohnutky. Adam i Ctirad začínají svoji dráhu v prostředí YouTube v rámci vlastní pedagogické činnosti, kde videa plní úlohu zprostředkování vzdělávacích obsahů pro malý okruh studentů. Jejich následné zaměření je ale rozdílné. Ctirad videa nadále tvoří pro vlastní žáky. Adam se jimi snaží oslovit co nejširší skupinu recipientů. Tento rozdíl pak můžeme pozorovat na odlišném profesním sebepojetí obou učitelů. Ctirad využívá YouTube k podpoře profesního sebepojetí učitele, kdy se popisuje jako učitel, který hledá vhodný nástroj k výuce svých žáků. Adam naopak začíná YouTube, na základě interakcí s kolegy tvořícími vzdělávací videa, využívat k dalšímu profesnímu rozvoji.

\subsection{Sebeoceňování učitele-youtubera a motivace $k$ další tvorbě}

Sebeoceňování učitele je hodnoticí složkou jeho sebepojetí a je spojeno mimo jiné s vnímáním vlastní úspěšnosti v profesi. V prostředí YouTube je možné úspěšnost spojovat s počtem odběratelů či zhlédnutí videí nebo se zpětnou vazbou v komentářích pod videi. Postoj učitelů Adama a Ctirada k počtu zhlédnutí jejich videí se různí. Adam: „Vidělo to docela hodně lidí a vypadalo to, že je to zaujalo, a ted' ti lidi mi začali ř́kat, jestli bych nenatočil třeba ještě něco, a já měl radost, že se to někomu líbí. A tak jsem ty videa začal postupně přidávat." Je patrné, že Adama množství zhlédnutí nejen těší, ale je pro něj také motivační, považuje je za důvod k dalšímu natáčení. Ctiradův postoj k počtu zhlédnutí jeho videí je odlišný: „A víte, možná to bude znít blbě, já to trošku přirovnám, jak je autorům učebnice, když ho lidi chválí a vidí, že někdo učí podle jeho učebnice. Já mám 45000 zhlédnutí videa o zlomcích. 45000 ! To je náklad velký učebnice!" Ctirad úspěch na YouTube zasazuje do školního prostředí přirovnáním videa k učebnici. Množství zhlédnutí však pro Ctirada nepředstavuje motivaci k další tvorbě. Vnímání vlastního úspěchu je u něj spojené s dokončením úkolu a s pocitem hrdosti, kdy je jeho učebnice na YouTube hotová a on již nemá potřebu další tvorby. Ctirad již 
natočil videa pokrývající kurikulum matematiky druhého stupně základní školy a nová videa již nenatáčí. ${ }^{13}$

Mimo popsanou sledovanost videí mají učitelé coby tvůrci na YouTube zpětnou vazbu od recipientů v podobě komentářù. Oba učitelé Adam a Ctirad komentářů ke komunikaci s recipienty hojně využívají.

Adam: Mám radost, že mi něco napíšou, a když si to přečtu, tak mi přijde slušný odpovědět. Možná jsem se ale jenom neadaptoval na to online prostředí a nevím, jestli se to má dělat nebo ne. [...] A já jsem hrozně jako ješita, jak říká moje žena, takže mi to hrozně dělá radost, že ti lidi píšou, že se jim to líbí a tak. Mě to hrozně jako těší, takže to je taková moje motivace [k natáčení] jako velká.

Adam recipientům na komentáře odpovídá spíše intuitivně, aniž by měl jasný cíl svého konání. Interakce s recipienty, spojené s pozitivním hodnocením Adamovy práce, jsou jeho motivací $\mathrm{k}$ tvorbě vzdělávacích videí. Ctirad má ke komentářum obdobně jako Adam pozitivní vztah. Na rozdíl od Adama má Ctirad dané postupy při reagování na komentáře.

Ctirad: Mě jako každého ješitného chlapa těší každotýdenní komentáře, lidi z České republiky, ze Slovenska, že mi prostě děkují, tadyto mně pomohlo, že od těch učitelů to nepochopili, ty komentáře jsou tam strašně zajímavé, strašně krásné. [...] Ty komenty mě těší, pečlivě je sleduju. Taky na ně téměř na každý mám pravidlo, že odpovím, to dělám $v$ rámci prevence proti vyhoření, prostě to dává ten smysl.

Jak učitel Ctirad uvádí, odpovídání na komentáře se stalo jeho vžitým rituálem, který dodává smysl jeho profesi. Komentáře jsou jeho portfoliem ${ }^{14}$, kterým sám sebe přesvědčuje o svých kvalitách učitele ${ }^{15}$. Interakce s recipienty přinášejí oběma učitelům pozitivní emoce a zvyšují jim sebehodnocení; jak sami ř́kají, jde i o ješitnost.

Důvody k interakci s recipienty vycházejí z profesního sebepojetí učitelů. Vztah s recipienty a úspěch na YouTube je ve Ctiradově př́ípadě úžeji navázaný na profesní dráhu učitele. Interakci s recipienty videí Ctirad vědomě

13 Ctirad v komentářích na YouTube: „Díky za uznání. Máte pravdu, že je to staré. Holt se videím pro své žáky věnuji už asi sedm roků.“

14 Ctirad v komentáŕích na YouTube: „Tak tento komentář si zakládám do svého portfolia na čestné místo, moc za něj děkuji a vážím si jej.“

15 Např́íklad v náročných situacích, kdy by mohl o sobě jako učiteli pochybovat. Ctirad v komentářích na YouTube: „Děkuji za pochvalu. Potěší takto koncem roku.“ 
využívá ke zvyšování své sebeúcty coby učitele. Přesto se Ctirad nenechává přímo ovlivňovat komunitou recipientů jeho videí z hlediska natáčení, videa tvoří primárně pro své žáky.

Dle analýzy komentářů se potvrzuje, že Ctirad stále sleduje diskusní vlákna k veškerým svým videím a interaguje s recipienty. Významné zde je, že Ctirad vědomě využívá kontakt s recipienty jeho videí jako motivaci pro svoji další práci učitele a jako potvrzení vlastní dobré praxe. Na základě interakcí $\mathrm{s}$ recipienty se považuje za úspěšného učitele. Interakcí cíleně využívá k vyrovnání se s dílčími neúspěchy v pedagogické činnosti. Adam vnímá interakce na YouTube jako doklad kvality své práce. Pozitivní ohlasy na svoje videa vnímá jako motivaci k tomu, aby svou videotvorbu systematicky posouval dále. Snaží uspět jako youtuber, zvyšovat kvalitu svých videí, potažmo svoji diváckou základnu.

\subsection{Sebeobraz učitele-youtubera ve vztazích na YouTube}

Sebeobraz učitele je deskriptivní složkou profesního sebepojetí. Učitelé zde popisují svoji pedagogickou činnost na YouTube a její význam ve vztahu k žákům a kolegům. Pocitované působení na žáky je silné u učitele Ctirada. To se projevuje vnímáním vlastního účinku na učení recipientů. Ctirad: „Když bysme vzali odběratele, tak některým pomůžu [s osvojením učiva], některé jsem zachránil od reparátu, případně repec díky tomu udělali." Důležitou součásti Ctiradova sebeobrazu učitele je, jak vnímá význam svého působení na žáky, kteří mají horší studijní výsledky. Zájem o recipienty a s ním spojené zjištování vlastního účinku na jejich studijní výsledky projevuje i v komentářích. ${ }^{16}$ Učitel Adam ve vztahu ke svým recipientům přikládá význam spíše jejich motivaci k životním změnám než školním výsledkům:

Jakože od té doby za poslední rok mi mohlo napsat e-mail, já nevím, 300 lidí, a ti lidi mi třeba píšou ty svoje životní př́iběhy a jak se třeba začli učit [cizí jazyk] a já mám z toho třeba hroznou radost, že oni píšou, že jako díky mně. Anebo jeden mi napsal, třeba z Kanady, že tam odjel na základě toho.

Adam sám sebe vnímá spíše jako motivátora, který předává recipientům své nadšení pro cizí jazyk. Předávání znalosti jazyka pak vnímá jako předávání potenciálu k životním změnám. Jeho vztah s recipienty je vzhledem k jeho

16 Recipient 1: „Díky, snad to pomůže při zítřejším reparátu. Pomohl jste mi!“

Ctirad: „A pomohlo to u reparátu?“

Recipient 1: „Ano, pomohlo. :) Udělala jsem ho. :)“ 
profesním ambicím v prostředí YouTube i obchodní. Adam: „Tak tím se vlastně propaguju sám, že si buduju značku ,Adam' a že se snažím být na ty lidi hodnej." Navazování vztahu s recipienty v prostředí YouTube je zde prostředkem k budování skupiny potenciálních zákazníků a prostředkem k propagaci vlastní pedagogické činnosti.

Součástí profesního sebepojetí učitele je vnímání sebe ve vztahu s kolegy učiteli. Právě učitelé jsou v kontextu YouTube specifickou skupinou recipientů a zároveň redistributorů vzdělávacích videí. Učitel Ctirad využití videí ve výuce ostatními učiteli vnímá jako velmi časté: „Mnoho, a to mnoho odhaduju na desítek možná i stovek, učitelů používá mé videonávody pro usnadnění své vlastní výuky. [...] Na jednom prestižním pražském gymnáziu paní učitelka, paní profesorka pustila můj videonávod ve výuce." Mimo působení na žáky Ctirad vnímá své působení i na práci českých učitelů. V citovaném příkladu dochází u Ctirada prostřednictvím videí k porovnání s ostatními učiteli různých typů škol, konkrétně víceletého gymnázia a základní školy.

Adam je na základě své tvorby na YouTube kontaktován kolegy i společnostmi, které se věnují natáčení vzdělávacích videí profesionálně. Adamova spolupráce s nimi vede také k jeho profesionalizaci v natáčení. Adam: „V tom ABC [anonymizováno] mi říkali, abych nedělal něco, co by mi bylo vyloženě cizí. Protože oni sami koukaj' na ty videa na YouTube a hledají tam lidi jako talenty." Adam si díky spolupráci uvědomuje vlastní kvality a do vztahu se společnostmi vstupuje autonomně, kdy jsou uznávány jeho postupy při učení.

Ctiradův sebeobraz je ve vztahu k žákům a učitelům spojen s pomocí. Ctirad působí především jako učitel svých prezenčních žáků. Pedagogické působení na YouTube a vliv na recipienty je spíše bonusem, který Ctirada utvrzuje $\mathrm{v}$ učitelské praxi. Adam působí ve vztahu k recipientům videí jako motivátor a vzhledem k profesnímu záměru v online vzdělávání i jako obchodník, který propaguje své služby. Adam využívá nabízených možností ke spolupráci, které vedou $\mathrm{k}$ jeho větší profesionalizaci v online prostředí.

\subsection{Prospektivní Já učitele-youtubera}

Budoucí cíle, očekávání a perspektiva učitelů představuje jejich prospektivní Já. Přestože se oba učitelé Adam a Ctirad považují za úspěšné v prostředí YouTube, pouze u učitele Adama tento úspěch ovlivňuje jeho profesní směřování a je pro něj motivující k pokračování v jeho tvorbě. Jak vyplývá z rozhovorů, může být profesní směřování a s ním spojené prospektivní Já učitelů v prostředí YouTube ovlivněno jejich spokojeností v roli učitele. 
Adam: Mně to jako přijde, že $v$ tom našem školství není žádná motivace se zlepšovat a udržet si tu motivaci sám podle mě jde třeba pět let. [...] A vidím to trošku i na sobě, proto já mám letos rok, kdy nebudu učit, budu učit v Anglii. No, a že když člověk učí úplně blbě, tak to funguje tak, že dostaneš ty úplně stejný peníze, jako když učíš dobře. A právě v těch videích se můžou ti lidi cítit jako porovnáváni a pak si můžou tu motivaci udržet, aspoň na mě to funguje, že když vidím, jak to někdo dělá dobře, tak mám taky snahu se zlepšit.

Učitel Adam se v rozhovoru dostává ke kritice ohodnocování učitelů, pocit'uje nespravedlnost $\mathrm{v}$ ohodnocení v porovnání s kolegy a jejich výkonem. Je patrné, že mu jeho povolání neposkytuje dostatečný profesní růst a finanční ohodnocení. Prostředí vzdělávacích online videí pak vnímá jako transparentnější a svobodnější. S tímto je spojená motivace a možnost porovnání svého výkonu s kolegy. Úspěch zde záleží na schopnostech a výkonu jednotlivců, proto se Adam v tomto prostředí cítí motivovanější než ve školství. Naopak ustálenost ve vlastní profesi a spokojenost s ní se projevuje v př́ípadě učitele Ctirada:

Já jsem úředník, já jsem zástupce ředitele, mám $\mathrm{k}$ tomu ještě nějaký metodický věci, takže já si chodím na sedm hodin tejdně zaučit, a kdyby mě nebavila moje práce, tak ji nedělám ani minutu. [...] i děti mě zastavují na chodbách a ř́kají: „to už jsme od vás viděly“, někdy mi i v hodině ř́kají: „pane učiteli, to už jste říkal na videu."

U Ctirada je patrná značná profesní ukotvenost. Je profesně vytížený a nemá potřebu vyhledávat další pracovní př́ležitosti. Dalším faktorem je jeho kladný vztah k samotnému vyučování, chodí si „zaučit“, což naznačuje jeho pojetí pedagogické činnosti jako zábavné až relaxační činnosti. Stejně tak je pro něj zásadní vztah s jeho žáky a videa natáčí v prvé řadě pro ně. Adam vyvíjí snahu o prosazení se v prostředí YouTube. Je patrný vývoj ve formě jeho videí a snaha o jejich vylepšování, například prací s postprodukcí. Adam: „Mám do budoucna takový sen, že já bych byl, že bych se mohl aspoň částečně živit, že bych mohl natáčet ty videa a že by mi to generovalo ty peníze bez toho, že bych tam musel nutně být." Adam se snaží proniknout do prostředí YouTube a získanou reputaci a vazby využít také komerčně. Svoji tvorbu na YouTube vnímá i jako budoucí profesní perspektivu. Ctirad se přímo nevyjadřuje ke svému sebepojetí v prostředí YouTube. Z rozhovoru je jasné, že má o YouTube velký zájem a tvorba videí, jejich komentování i zájem o vývoj sledovanosti vyplňovaly a stále vyplňují množství jeho času. 
Ctirad: Třeba mě tam fascinují ty statistiky počtu zhlédnutí. Tam opravdu na počtu zhlédnutí mých videí se dá vidět, jak přistupují žáci České republiky ke vzdělávání. Tam je vidět, kdy se učí, jak, kolik. Přesně tam jsou vidět na analýze přestávky, prázdniny, přesně tam je vidět, kdy jsou čtvrtletky, kdy hrozí reparáty. Je tam vidět jednotlivé dny v týdnu, jednoznačně poznáte i kratší prázdniny.

Tazatelka: To je hrozně zajímavý, takže vy sledujete ty vaše statistiky?

Ctirad: No, občas ze srandy se na ně kouknu a třeba je pak používám pro výuku práce s grafem.

Ctirad se v rozhovoru ke statistikám sledovanosti ještě mnohokrát vracel. Na přímou otázku, zda statistiky sleduje, má tendenci tento svůj přístup zlehčovat. Výrazně se zde projevuje profesní sebepojetí učitele, který statistiky využívá při školní výuce. Sebepojetí youtubera, který se těší ze své sledovanosti, tak má pro Ctirada spíše pejorativní tón. Učitel Ctirad na rozdíl od Adama směřuje k ideálnímu Já školního učitele a podřizuje tomu své chování na YouTube.

Oba učitelé se snaží využít YouTube k dosažení ideálního Já dle vlastního profesního sebepojetí. Učitel Adam pocit'uje určitou nespokojenost ve své profesi učitele a snaží se proto o jeho regulaci, prostředí YouTube vnímá jako jeden z prostředků, který mu pomáhá dosáhnout změny. U učitele Ctirada naopak profesně bylo ideálního Já dosaženo. Ctirad se proto snaží využít YouTube v tomto kontextu, kdy si prostřednictvím YouTube upevňuje přesvědčení o svých schopnostech učitele a vylepšuje prostřednictvím videí primárně svoji vlastní výuku. Ctiradovo prospektivní Já na YouTube je založeno na předpokladu výběru renty z dř́ve naakumulovaného kapitálu. Ctirad svoji video-učebnici matematiky považuje za dokončenou a pod heslem „matematická videa nezastarávají" ${ }^{17}$ předpokládá, že její úspěch bude pokračovat i v budoucnu.

\section{Diskuse a závěr}

Pravdová (2013) ve své studii uvádí, že studentka učitelství má v počátcích obavy z nároků na profesi. Učitelé Adam a Ctirad k publikování na YouTube přistupují s prekonceptem YouTube jako sdíleného úložiště videí pro své

17 Ctirad v rozhovoru: „Ne, nezastarávají. Opravdu, matematická videa nezastarávají, sorry, já učím, matematický videa nezastarávají, prostě ne, co chcete, aby na matematickým videu zastaralo? Zlomky se učí furt stejně!“ 
žáky. Nekladou na sebe proto jiné nároky, než jak tomu je v jejich běžné výuce. Jejich vztah k YouTube je spojen s představou tohoto prostředí jako uzavřeného systému, který bude sloužit zejména jejich žákům pro doplnění výuky. K retrospektivnímu Já na YouTube se tedy nevztahují žádné ambice $\mathrm{v}$ souvislosti s tvorbou mimo okruh předem určených recipientů z řad jejich žáků. Sebeobraz učitelů Adama a Ctirada na počátku jejich publikování na YouTube je založený na inovaci vlastní pedagogické činnosti.

V průběhu působení na YouTube začínají učitelé Adam a Ctirad YouTube vnímat jako otevřený systém, který jim umožňuje interagovat s jeho uživateli, jako tomu je na sociálních sítích. Obsah sebepojetí se utváří podle Blatného (2010, s. 118) právě v procesu socializace a je určen osobní zkušeností jedince. Během socializace učitelů Adama a Ctirada v prostředí YouTube, zejména díky interakcím s recipienty a ostatními tvůrci videí, dochází u obou k formování jejich sebepojetí. Pod vlivem pozitivní zpětné vazby pramenící z interakcí na YouTube mají oba učitelé vysoké sebeoceňování.

Socializace $\mathrm{v}$ online prostředí je krokem $\mathrm{k}$ budování vztahu mezi učitelem a studentem. Dle výzkumných studií je utváření vztahu mezi učitelem a studentem významné právě $v$ online prostředí, kdy prrítomnost učitele ve videu předchází pocitu izolovanosti studenta (Borup et al., 2012) a vede ke zlepšení přístupu k učení i studijních výsledků studentů (Kim \& Thayne, 2015), podobně pak $\mathrm{k}$ větší chuti $\mathrm{k}$ učení a užitečnosti videa (Lyons et al., 2012). V daném kontextu význam této studie spočívá v prokázání působení vztahu s online studenty i na učitele Adama a Ctirada. V obou popsaných př́padech interakce s recipienty učitele pozitivně ovlivňují, zvyšují jejich sebeoceňování. Pozitivní sebeoceňování na základě interakcí na YouTube je nejvýraznějším znakem profesního sebepojetí učitelů Adama a Ctirada. Promítá se i do jejich pedagogické činnosti. Ctirada pozitivní zpětná vazba pramenící z interakce s recipienty online podporuje $\mathrm{v}$ jeho pedagogické praxi na základní škole a ve vlastním sebehodnocení coby učitele. Adama natáčení videí a s ním spojená interakce s recipienty motivuje $\mathrm{k}$ další pedagogické činnosti a profesionalizaci v online prostředí. Ctirad není ovlivněn recipienty mimo okruh svých žáků v samotné tvorbě. Přesto nadále využívá YouTube ke komunikaci s recipienty jeho videí.

Výrazné sebeoceňování učitelů je významné i v kontextu subjektivně vnímané zdatnosti učitelů. Kašparová, Potužníková a Janík (2015) upozorňují na relativně nízkou subjektivně vnímanou zdatnost učitelů v České republice 
a nadprůměrně často se vyskytující pocit, že je učitelské povolání nevýhodné a ve společnosti nevážené. Reakce recipientů na Adamova a Ctiradova videa jsou ve většině případů pozitivní, oceňující a povzbuzující. Příjemné emoce pramenící z komunikace s diváky pak oba učitele vedou k potvrzování jejich profesního sebepojetí učitele a jejich víře ve vlastní schopnosti.

Pro profesní sebepojetí je důležitá také interakce s blízkými (rodinou, kolegy či přáteli). Ti jsou zprostředkovateli zrcadlového Já. Pravdová (2015) zrcadlové Já, tedy obraz, který učitelům o nich samých poskytuje jejich okolí, uvádí mezi významnými faktory ovlivňujícími sebepojetí. $V$ případě učitele Adama můžeme vysledovat podporu ze strany kolegy Evžena, který působí na YouTube. Ctirad je oceňován svými žáky a jejich rodiči, případně i kolegy ve škole. Zrcadlové Já Adama a Ctirada tak koresponduje s ideálním Já obou učitelů, kdy se Adam více vidí v roli youtubera a Ctirad naopak v roli učitele.

Praktickým aspektem youtuberství je možnost finančního zisku a je možné na něj nahlížet jako na prostředek ke zlepšení finanční situace učitelů. Podle zprávy OECD (2017) dosahují učitelé v České republice 58-61 \% průměrné mzdy českého vysokoškoláka (v závislosti na stupni školy, kde vyučují). Proto může být pro české učitele, jako pro učitele Adama, youtuberství zajímavé například i z důvodu propagace vlastní pedagogické činnosti a možnosti navázání spolupráce se vzdělávacími společnostmi. Učitele Adama možnost finančního zisku prostřednictvím YouTube dostává do role profesionála v oblasti vzdělávacích online videí. Na jeho tvorbě je tedy patrná snaha o stálé vylepšování formy videí i o co nejlepší předání obsahu. Adam se snaží uspět u diváků svých videí, a proto obsah předává zábavnou formou a co nejsrozumitelněji. Profesní ukotvenost učitele Ctirada spojená se zátěží $\mathrm{v}$ roli zástupce ředitele jej vede $\mathrm{k}$ pasivitě ve tvorbě videí. Hlavní prioritou je tvorba pro vlastní žáky a vzhledem k naplnění kurikula nemá tendence natáčet nová videa. Časová úspornost a pragmatičnost spojená s tvorbou pro vlastní žáky vedou ke stagnující kvalitě videí. Učitel Ctirad předává obsah učiva velmi jasně a srozumitelně, takže videa plní funkci praktické učební pomůcky. Abstrahuje ale zábavnou formu či motivování recipientů.

Výzkumy zaměřené na identitu a sebepojetí učitele, například výzkumy Kelchtermanse (1993, s. 448), Beauchampové a Thomasové (2009) i Kimmonse a Veletsianose (2014), ukazují, že učitelské sebepojetí je dynamické. Limitem výzkumu tak zůstává, že data z rozhovorů s učiteli ilustrují pouze určitá stádia profesní dráhy učitelů Adama a Ctirada. Tuto skutečnost 
může částečně nahradit pozorování online aktivity v prostředí YouTube. Vzhledem k odlišnému přístupu učitelů došlo šest měsíců po ukončení sběru dat $\mathrm{k}$ výraznému vývoji sledovanosti. Ctiradův kanál vzhledem ke stagnaci v přidávání nových videí stagnuje i ve vývoji sledovanosti. Sledovanost Adamova kanálu naopak díky Adamově orientaci na profesionalizaci v prostředí téměř dvojnásobně vzrostla. ${ }^{18}$

Ve studii je představeno téma učitelů tvořících vzdělávací videa na YouTube z hlediska jejich profesního sebepojetí. Nabízí se další oblasti, kam je možné směřovat budoucí výzkum vzdělávání prostřednictvím YouTube. Tématem v této studii naznačeným je motivace učitelů k tvorbě videí, která zasluhuje více prostoru. Bohatým zdrojem dat na YouTube je diskuse recipientů a tvůrců videí v rámci sekce komentáře. Právě interakce v rámci komentářů jsou dobrým zdrojem dat pro smíšený výzkumný design. Teoretické rámce, které se jeví jako vhodné pro další zkoumání, jsou model TPCK (technologicko-pedagogicko-předmětové znalosti) či Community of Inquiry.

\section{Poděkování}

Na tomto místě chci poděkovat docentce Kláře Šed’ové, které vděčím za skvělé vedení při tvorbě článku v rámci kurzu Autorský seminář. Můj dík patří i kolegyním z tohoto kurzu, Janě Sedláčkové, Kristýně Vlčkové a Kláře Harvánkové, za jejich rady a podporu.

\section{Literatura}

Alston, G. D., \& Ellis-Hervey, N. (2015). Exploring the nonformal adult educator in twenty-first century contexts using qualitative video data analysis techniques. Learning, Media And Technology, 40(4), 502-513.

Beauchamp, C. \& Thomas, L. (2009). Understanding teacher identity: an overview of issues in the literature and implications for teacher education. Cambridge Journal of Education, $39(2), 175-189$

Berk, R. A. (2009). Multimedia teaching with video clips: TV, movies, YouTube, and mtvU in the college classroom. International Journal of Technology in Teaching and Learning, 5(1), 1-21.

Blatný, M. (2010). Sebepojetí z pohledu sociálně-kognitivní psychologie. In M. Blatný (Eds.), Psychologie osobnosti. Hlavní témata, současné př́stupy (s. 105-136). Praha: Grada.

18 Pro tuto studii byli vybráni dva učitelé na podobné úrovni sledovanosti. Ctiradův kanál má 425800 zhlédnutí (data k 10. 9. 2017) oproti původním 400 000. Sledovanost Adamova kanálu vzrostla z 601100 na 1013200 zhlédnutí (data k 10. 9. 2017). 
Boling, E. C., Holan, E., Horbatt, B., Hough, M., Jean-Louis, J., Khurana, C., ... Spiezio, C. (2014). Using online tools for communication and collaboration: Understanding educators' experiences in an online course. The Internet and Higher Education, 23, 48-55.

Borup, J., West, R. E., \& Graham, C. R. (2012). Improving online social presence through asynchronous video. The Internet and Higher Education, 15(3), 195-203.

Desmet, C. (2009). Teaching Shakespeare with YouTube. English Journal, 99(1), 65-70.

Dreon, O., Kerper, R. M., \& Landis, J. (2011). Digital storytelling: A tool for teaching and learning in the YouTube generation. Middle School Journal, 42(5), 4-10.

Haase, D. (2009). The YouTube makeup class. The Physics Teacher, 47(5), 272-273.

Hibbert, M. C. (2014). What makes an online instructional video compelling? Educause Review Online.

Chen, H., \& Summers, K. L. (2015). Developing, using, and interacting in the flipped learning movement: Gaps among subject areas. International Review of Research in Open and Distributed Learning, 16(3), 41-64.

Jones, T., \& Cuthrell, K. (2011). YouTube: Educational potentials and pitfalls. Computers in the Schools, 28(1), 75-85.

Kašparová, V., Potužníková, E., \& Janík, T. (2015). Subjektivně vnímaná zdatnost učitelů v kontextu jejich profesního vzdělávání: zjištění a výzvy z šetření TALIS 2013. Pedagogická orientace, 25(4), 528-556.

Kelchtermans, G. (1993). Getting the story, understanding the lives: From career stories to teachers' professional development. Teaching and Teacher Education, 9(5-6), 443-456.

Kellner, D., \& Kim, G. (2010).YouTube, critical pedagogy, and media activism. The Review of Education, Pedagogy, and Cultural Studies, 32(1), 3-36.

Kim, Y., \& Thayne, J. (2015). Effects of learner-instructor relationship-building strategies in online video instruction. Distance Education, 36(1), 100-114.

Kimmons, R., \& Veletsianos, G. (2014). The fragmented educator 2.0: Social networking sites, acceptable identity fragments, and the identity constellation. Computers \& Education, 72, 292-301.

Kozinets, R. V. (2010). Netnography: Doing ethnographic research online. London: Sage.

Mayora, C. (2009). Using YouTube to encourage authentic writing in the EFL classrooms. TESL Reporter, 42(1), 1-12.

Lazarová, B., \& Jůva, V. (2011). Učitelé a faktor času: o proměnách pracovního sebepojetí. Studia paedagogica, 15(2), 43-60.

Lukášová, H. (2015). Učitelské sebepojetí a jeho zkoumání. Zlín: Univerzita Tomáše Bati ve Zlíně, Fakulta humanitních studií.

Lyons, A., Reysen, S., \& Pierce, L. (2012). Video lecture format, student technological efficacy, and social presence in online courses. Computers In Human Behavior, 28(1), 181-186.

Mareš, J. (2013). Přehledové studie: jejich typologie, funkce a způsob vytváření. Pedagogická orientace, 23(4), 427-454.

Mareš, J., Slavík, J., Svatoš, T., \& Švec, V. (1996). Učitelovo pojetí výuky. Brno: Masarykova univerzita.

McGarr, O. (2009). A review of podcasting in higher education: Its influence on the traditional lecture. Australasian Journal of Educational Technology, 25(3), 309-321.

OECD. (2017). Education at a glance 2017: OECD indicators. Paris: OECD Publishing. 
Pravdová, B. (2013). Já jako učitelka: profesní sebepojetí studentky učitelství v posledním ročníku pregraduální př́ípravy. Pedagogická orientace, 23(1), 174-194.

Pravdová, B. (2015). Od dětského snu k vlastnímu pojetí výuky: proces utváření profesního sebepojetí studentů učitelství. In V. Švec, \& Bradová, J., et al. (Eds.), Učitel v teorii a praxi (s. 31-56). Brno: Masarykova univerzita.

Průcha, J., Walterová, E., \& Mareš, J. (2001). Pedagogický slovník. Praha: Portál.

Rotman, D., Golbeck, J., \& Preece, J. (2009). 'The community is where the rapport is - on sense and structure in the YouTube community'. Proceedings of the Fourth International Conference on Communities and Technologies (s. 41-50). ACM.

Rotman, D., \& Preece, J. (2010). The ,WeTube' in YouTube - creating an online community through video sharing. IJWBC, 6(3), 317-333.

Stake, R. E. (2013). Multiple case study analysis. New York: Guilford Press.

Sutherland, R., Armstrong, V., Barnes, S., Brawn, R., Breeze, N., Gall, M., \& Wishart, J. (2004). Transforming teaching and learning: Embedding ICT into everyday classroom practices. Journal of Computer Assisted Learning, 20(6), 413-425.

Švaříček, R., \& Šed'ová, K. (2007). Kvalitativní výzkum v pedagogických vědách. Praha: Portál.

Tan, E. (2013). Informal learning on YouTube: Exploring digital literacy in independent online learning. Learning, Media and Technology, 38(4), 463-477.

Thomson, A., Bridgstock, R., \& Willems, C. (2014). „Teachers flipping out“ beyond the online lecture: Maximising the educational potential of video. Journal of Learning Design, 7(3), 67-78.

Tondeur, J., Van Keer, H., Van Braak, J., \& Valcke, M. (2008). ICT integration in the classroom: Challenging the potential of a school policy. Computers \& Education, 51(1), 212-223.

Williams, D., Coles, L., Wilson, K., Richardson, A., \& Tuson, J. (2000). Teachers and ICT: Current use and future needs. British Journal of Educational Technology, 31(4), 307-320.

Yin, R. K., \& Campbell, D. T. (2003). Case study research: Design and methods. Thousand Oaks: Sage Publications.

Zounek, J., \& Šed’ová, K. (2009). Učitelé a technologie: mezi tradičním a moderním pojetím. Brno: Paido.

\section{Autorka}

Mgr. Klára Holíková, Masarykova univerzita, Filozofická fakulta, Ústav pedagogických věd, Arne Nováka 1, 60200 Brno, e-mail: klara.holik@gmail.com 


\title{
In-between teaching and YouTubering: Professional self-concept of teachers who publish educational videos on YouTube
}

\begin{abstract}
Video sharing has become a growing practice. YouTube in particular has a great amount of users, including educators. This study aims to explore professional self-concept of YouTube using teachers who engage in the production of educational videos. To accomplish this, a multiple case explanatory study is used. To collect data on teacher's perspectives, semi-structured interviews were used. Two extreme cases of teachers active on YouTube were selected. Important was the criteria of information-rich YouTube channel with large publishing and viewing activity. To triangulate different data, Netnographic methodology is used, so data published on teacher's YouTube channels could be examined. The qualitative analysis was based on a grounded theory approach. The analysis showed perception of self as a successful teacher and high self-esteem as dominant aspects of teacher's professional self-concept influenced by activity on YouTube. Teachers Adam and Ctirad started to use YouTube to provide for their student's educational needs. Appreciative reactions to Adam's and Ctirad's educational videos from other YouTube users, not just Adam's and Ctirad's students, made them change their behaviour on YouTube. Pleasant emotional experience based on the communication with viewers confirms their professional self-conceptions as teachers.
\end{abstract}

Keywords: teacher's self conception, YouTube, educational video, teacher's self-esteem, multiple case study, netnographic methodology

Klement, M., Dostál, J., Kubrický, J., \& Bártek, K. (2017). ICT nástroje a učitelé: adorace, či rezistence? Olomouc: Univerzita Palackého.

Monografie je zaměřena na problematiku využívání ICT nástrojů v práci učitelů základních a středních škol. Sumarizuje tak dílčí vědecko-výzkumné aktivity řešitelského kolektivu, které se zaměřují na problematiku využití informačních a komunikačních technologií ve vzdělávacím procesu s přesahem do oblasti netradičních vzdělávacích přístupů a integruje je do podoby komplexního výzkumu zaměřeného na možnosti a limity tohoto využívání ze strany učitelů základních a středních škol. Struktura monografie byla konstituována tak, aby čtenáři poskytla ucelený vhled do problematiky realizace, uspořádání a mezí ICT nástroji podporované výuky, s přesahem do problematiky plánování, návrhu a provedení pedagogického výzkumu za využití kvantitativních a multidimenzionálních statistických metod. 